\title{
Nytt tidsskrift om psykisk helsearbeid
}

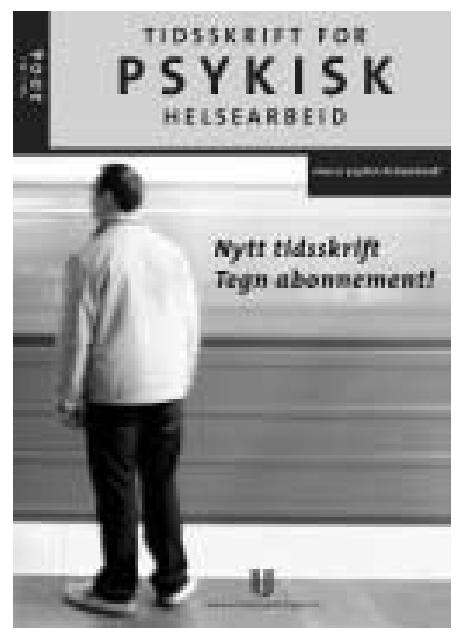

www.universitetsforlaget.no/tidsskrifter
Etter å ha kjempet for sin fødsel i snart fire år ser Tidsskrift for psykisk helsearbeid endelig dagens lys denne våren. Det skal fungere som en møteplass for alle som jobber innen fagfeltet.

Første nummer av tidsskriftet skal ta for seg det grunnleggende spørsmålet: $\mathrm{H}$ va er egentlig psykisk helsearbeid? Det er det nemlig et stort behov for å diskutere i følge den nybakte redaktøren Bengt Karlsson.

- Som tverrfaglig felt er psykisk helsearbeid nytt. Begrepet ble introdusert i regjeringens opptrappingsplan for psykisk helsevern i 1999. M en arbeidet med à definere innholdet $\mathrm{i}$ dette er kommet altfor kort. H er vil tidsskriftet spille en nøkkelrolle, håper Karlsson. $\mathrm{H}$ an er høgskolelektor ved $\mathrm{H} ø g s k o l e n$ i A gder og utdannet psykiatrisk sykepleier. Tangegodset i opptrappingsplanen ligger til grunn for det nye tidsskriftets målsetting og faglige profil.

- Psykiskelidelser har tradisjonelt vært behandlet individuelt, med medikamenter og terapi. Vi kan diskutere årsakene til en psykisk lidelse til vi blir blå, men det vi vet, er at en person med psykiske problemer virker på sine omgivel ser og vice versa. Psykisk helsearbeid skal i større grad ser på konsekvensene for nærmiljøet og se løsninger for den enkelte i denne sammenheng, sier Karlsson.

$H$ an nevner gode boligløsninger, muligheten til meningsfull aktivitet og sosiale nettverk som eksempler.

Terskelen for å bidra til tidsskriftet skal være lav. Derfor har redaksjonen opprettet en spalte som helter "fortellinger", der brukere av psykiatriske tjenester kan skrive om sine erfaringer med hjel peapparatet. 0 gså mestring og bedring er viktige stikkord for tidsskriftet.

- N ummer to skal derfor handle nettopp om det. Vi vil samle suksesshistorier fra hele landet. H vor har de fătt til godt

lokal basert psykisk helsearbeid, og hvorfor? D et kan dreie seg om vellykket integrasjon for eksempel, sier Karlsson.

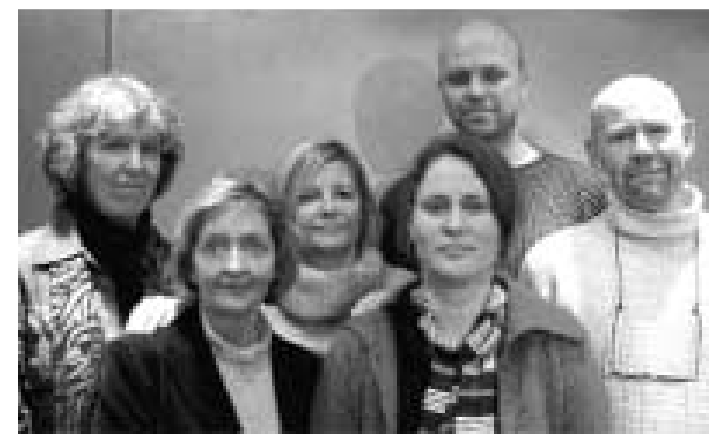

edaksjonen (fra venstre): $M$ arit Borg, O laug K rogsæter. A nne-M argrethe $\mathrm{H}$ olmboe, Susanne Dietrichsson. A nders Johan W. A ndersen og Bengt Karlsson

\section{Nye bøker}

\section{Leenaars, A ntoon A \\ Psychotherapy with suicidal people: a person-centred approach}

Hoboken, N.J. : John Wiley \& Sons, 2004. $-460 \mathrm{~s}$.

ISBN : 0-470-86342-0

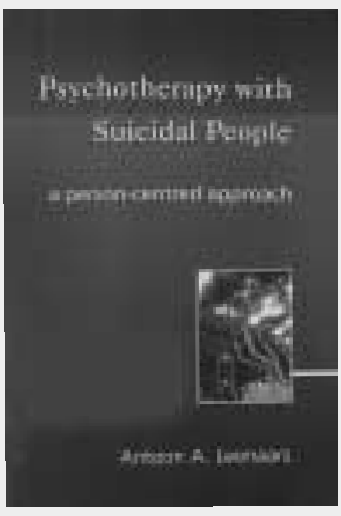

King, Robert A . I A pter, A lan (eds.)

\section{Suicide in children} and adolescents Edited by Robert $A$. King, A lan A pter. $\mathrm{N}$ ew York: Cambridge U niversity Press, 2003. $-320 \mathrm{~s}$.

ISBN : 0-521-62226-3

\section{Fortsatt fra s.22 - Ekblad og Shahnavaz}

H erlihy J, Scragg P, Turner S. D iscrepancies in autobiographical memoriesimplications for the assessment of asylum seekers: repeated interviews study. British M edical Journal 2002; 324: 324-7.

Hollifield M, Warner TD, Lian N, Krakow B, Jenkins JH, Kesler J, Stevenson $J$, W estermeyer $J$. Measuring trauma and health status in refugees. A critical review. JA M A 2002; 288(5): 611-621. Landstingsförbundet. (2003). Sjukvård åt asylsökande, omfattning och kostnader under år 2002. PM 2003-06-10

Lindencrona $F$, Johansson Blight $K$, Ekblad S. Teori och val av metod för att studera hälso-främjande insatser ur ett transkulturellt perspektiv. $\mathrm{N}$ ordisk Psykologi 2002; 54(1): 7-26.

Lundberg 0 . N yström Peck M. A simplified way of measuring sense of coherence. Experiences from a population survey in Sweden. European Journal of Public Health 1995; 5(1): 56-59.

$M$ ehlum $L$. Suicidal ideation and sense of coherence in male conscripts. A cta Psychiatr Scand 1998: 98 (6): 487-92.

M ollica RF, Wyshak $G$, de M arneffe $D$, Tu B, Yang T, Khuon, F, Coelho R, Lavelle L. H opkins Symptom Checklist - $25 \mathrm{M}$ anual. C ambodian, Laotian and
V ietnamese versions. $\mathrm{H}$ arvard School for Public H ealth, 1985.

M ollica RF, C aspi-Yavin Y, Lavelle J, Tor S, Yang T, Chan S, Pham T, Ryan A, de $M$ arneffe $D$. T he $H$ arvard Trauma $Q$ uestionnaire (H T Q). M anual for use with C ambodian, Lao and Vietnamese versions. $H$ arvard Program in Refugee Trauma, $\mathrm{H}$ arvard School of Public H ealth, 1994.

Petrie K, Brook R. Sense of coherence, self esteem, depression and hopelessness as correlates of reattempting suicide. British Journal of Clinical Psychology 1992: 31: 293-300.

Silove D, Ekblad S. (red) H ow well do refugees adapt after resettlement in Western countries? A cta Psychiatrica Scandinavia 2002; 106: 401-402.

Steel Z, Silove D, Phan T, Bauman A . Long-term effect of psychological trauma on the mental health of Vietnamese refugees resettled in A ustralia: a population-based study. The Lancet 2002: 360: 1056-1062.

W eisæth $L$. A study of behavioural responses to an industrial disaster. A cta Psychiatr Scand 1989 ; 80 (Suppl. 355): 38-49. 